\title{
Migration and Power Politics: The Settlement of Georgian Immigrants in Turkey (1878-1908)
}

\section{Oktay Özel}

To cite this article: Oktay Özel (2010) Migration and Power Politics: The Settlement of Georgian Immigrants in Turkey (1878-1908), Middle Eastern Studies, 46:4, 477-496, DOI: 10.1080/00263206.2010.492984

To link to this article: https://doi.org/10.1080/00263206.2010.492984

曲 Published online: 06 Aug 2010.

Submit your article to this journal $\pi$

LII Article views: 440

Citing articles: 3 View citing articles 5 


\title{
Migration and Power Politics: The Settlement of Georgian Immigrants in Turkey (1878-1908)
}

\author{
OKTAY ÖZEL
}

A notable outcome of the Ottoman-Russian war of 1877-78, known also as '93 Harbi', was the mass migration to Ottoman Anatolia of various Turkish and Muslim populations from the territories in the Balkans and Caucasus lost by the Ottomans. The research so far has produced a general framework for the processes of both the migration and the settlement of the immigrant groups. This also applies to the emigration of Muslim Georgians from the Batum region and the settlement of the immigrant families in Anatolia.

From the existing studies, ${ }^{1}$ it appears that the Ottoman government policy of settling the Georgian immigrants in the central Black Sea region between the towns of Ordu and Samsun was not significantly different from similar processes elsewhere in Anatolia: the immigrants from Georgia arrived at intervals over a five year period by boat or over land. They were first transferred to temporary destinations in a relatively orderly manner, where they were expected to be hosted by native Muslim families on their lands and in their houses until eventually being allocated land of their own to settle permanently. Thus, in time, new immigrant villages emerged in the countryside.

However, the details of the settlement process differed in each situation, namely in the ways immigrant families behaved, how they were treated by the natives, and the manner in which the migrants and the natives interacted. The consequences, which often led to serious tension and conflicts, were different too. In certain cases such problems appear to have further antagonized pre-existing local power struggles, affecting the socio-political atmosphere and requiring all parties involved to reposition themselves in accordance with the changing conditions and alliances. The process, then, usually resulted in direct or indirect intervention by the central government.

The present study is about one of these cases, attempting to make sense of certain characteristics of the settlement process of the Muslim Georgian immigrants in and around the district of Ordu during the decades following the Ottoman-Russian War of 1877-78. It also aims to provide a foundation for a larger framework of what might be termed 'politics of migration' with a particular emphasis on the sociopolitical aspects and the power struggle revolving around the immigrants, their settlement process and the complex relations among their leadership, Trabzon 
governors and the Palace in Istanbul. The focus of the study is on the immigrants themselves with occasional remarks on the position of the local nobility about which little is known.

The oral information from third generation Georgian immigrants tells that their grandparents came to the central Black Sea town of Ordu and the surrounding districts of Fatsa and Ünye during the years following the '93 Harbi'. Their story of the first arrival of the immigrants is as follows: after their land of origin was ceded to Russia, Muslim Georgians of the Batum-Çürüksu region were encouraged by the Ottoman authorities to migrate to Anatolia. As the new Russian administration of the region also exerted pressure on the Muslim inhabitants of the region, most of the Muslim families decided to leave their land to settle in Anatolia under Ottoman rule. $^{2}$ The Ottoman administration had a plan to direct these migrants to the area between Adapazarı and Bursa. However, the group in this study, closely connected to an influential local leader, Çürüksulu Ali Pasha (Ali Pasha of Çürüksu), is said to have suffered from sickness during the difficult sea voyage. When the three ships of the convoy reached the shores of Ordu, the migrants threatened the captains, demanding to land and settle in Ordu. This demand was forwarded to Istanbul. Eventually, after some three days of negotiation, the migrant families were given permission to land at Ordu. Thus, according to the story, their coming to the region was not a result of the original plan of the Ottoman government; it was purely accidental. $^{3}$

One may think that this was no more than many stories of migration, each coloured and enriched over time by the migrants themselves who creatively inserted elements according to their imagination. However, this particular story does appear to have some truth in it. Research into archival materials available on the actual process of the migration revealed British consular reports on cases in which some ships carrying hundreds of migrant families towards Bursa were in fact stopped by their passengers on the way, the immigrants eventually landing in Ordu. ${ }^{4}$ This record dated 1879 falls only a few months after the beginning of the mass migration of the Muslim Georgians under the close scrutiny and control of the Ottoman central and local authorities as well as the foreign consuls. ${ }^{5}$ A French consular report of the same date particularly emphasizes that among those coming to Ordu, along with ordinary immigrant families; there were also rich and prominent figures of the BatumÇürüksu region. ${ }^{6}$ These were possibly immediate associates of Ali Pasha.

The next stages of the migration can be followed from both Ottoman and British sources. During the first two years of the migration, between 1879 and 1881, some 6,000 Georgian households (roughly 30-40,000 individuals) migrated to ports in the Province of Trabzon. Of these, some 4,500 families arrived in the districts (kaza) of Ordu, Fatsa and Ünye. Two thousand of these families settled in the district of Ordu alone. $^{7}$ Seven months later, in February 1882, this time according to the figures of Çürüksulu Ali Pasha himself, who by then had been appointed as the official responsible for settling the migrants in the region (fahri iskân memuru), the total number of Georgians who had already emigrated to Ottoman Anatolia by sea was around 80,000; the number of people who came overland was around 40,000. Ali Pasha went on to state that at the time a further 80,000 were also making 
preparations to emigrate from what had once been Ottoman Georgia, now ceded to Russia. $^{8}$

However, during the summer of 1881 drought and famine affected the entire province of Trabzon so further migration was postponed until 1883 (see below). It is highly likely that this meant more hardship for those Georgians waiting to migrate to Anatolia, most of whom had already sold their houses and lands, and were thus forced to spend months in difficult conditions in and around the port city of Batum from where they would embark for Anatolia. In the meantime, in Anatolia, the Ottoman government made attempts to relieve both native peasants and Georgian immigrants in the Province of Trabzon by transferring grain and corn from other parts of the country. From the arrangement between Russia and the Ottoman Empire, which extended the period of migration for two more years, one may assume that a second wave of migration took place, perhaps on a smaller scale, during the years 1883-84. It is not unreasonable then to suppose that during this second wave some of the remaining 80,000 Georgians, who were reported to have been waiting for migration, might have also migrated to Anatolia. If these reports are not exaggerated, ${ }^{9}$ an estimated total of minimum 150,000 Georgians can be assumed to have migrated to the Ottoman territories during the five-year period following the Treaty of Berlin (1878). Most of these immigrants were directed towards regions further west, such as Samsun (including Terme, Çarşamba and Bafra districts), Sinop, Kocaeli, Adapazarı, İnegöl and Bursa while a few smaller groups were settled in the interior of the Black Sea region, in districts such as Sivas, Tokat and Amasya. ${ }^{10}$

When looking at the general picture of the districts of Ordu, Fatsa and Ünye, one observes a fairly gloomy picture: a great portion of the native Muslim peasants had small lands cultivated for subsistence, while the rest, including most of the Christian peasants, were either tenants or labourers on lands owned by the local notable $a \breve{g} a$ and bey families, who exerted unrestricted and arbitrary power in the region. ${ }^{11}$ The native populations in the Ordu, Fatsa and Ünye districts were predominantly Muslims, with Christian (Greek and Armenian) minorities (Table 1).

The majority of Christian families lived in towns and cities along the coast, engaging in trade and crafts. Along with a number of prominent Muslim families, they represented the emerging local bourgeoisie, soon to develop a sense of national awakening, especially from the late 1880s onwards. Another factor worth noting is the tension between the Orthodox Armenians and Greeks arising from the activities of a small group of Protestant and Catholic Armenians under the influence of American Protestant missionaries. ${ }^{12}$

The native Muslim population of these districts, on the other hand, was stratified into three main groups, with the big landholding notables at the top, the peasants at the bottom, and the emerging urban trading bourgeoisie in between. One should also mention the Circassian immigrants who had been in the western districts of the region (Ünye, Terme, Çarşamba districts of Canik sub-province) since the $1860 \mathrm{~s}$ and were proving to be a serious threat to both local peasantry and rural notable families. However, this type of social division tended primarily to affect the peasantry, both Muslim and non-Muslim, and all were living under extremely harsh conditions, with pressure from local notable landholding families. ${ }^{13}$

The arrival of the Georgian immigrants made the situation of the Muslim peasantry even worse. The native population was not in any way prepared for the 
Table 1. Native populations in the Ordu, Fatsa and Ünye districts (males only)

\begin{tabular}{lccc}
\hline District & Muslim & Greek & Armenian \\
\hline Ordu & 32,958 & 4969 & 3230 \\
Fatsa & 11,446 & 644 & 364 \\
Ünye & 11,007 & 1684 & 1634 \\
\hline
\end{tabular}

Source: PRO, FO 195/1329 (year: 1879-80).

accidental arrival of such a great number of unexpected guests. They literally were guests, because, according to the regulation and usual practice of the Ottoman government, these immigrants were to be welcomed primarily by the local Muslim peasants. They were responsible for the temporary settlement of these people on their lands. At least on paper they were required to provide the newcomers with shelter and food until each family was given a piece of land to settle on. ${ }^{14}$ In reality, there are reports regarding natives' (including the non-Muslims) unwelcoming attitude and complaints, even upon the rumours of the possibility of a large number of immigrants ending up in their region. In the summer of 1881, severe drought caused famine, making the situation unbearable for both native peasants and newcomers. ${ }^{15}$ The natives were hardly able to feed themselves and were losing their animals. As for the immigrants, their conditions were even harder: without proper land to grow even subsistence amounts of vegetables and crops, most of them had neither proper shelter nor money to buy basic food or goods for survival. During the first wave of migration, only a small proportion of immigrants were provided with lands that had once belonged either to peasants who had gone to the war as soldiers and never returned, or to women left behind by their husbands. In Fatsa, for example, one-third of the immigrants who arrived in 1879 were still landless and homeless a year later, while the remainder had been settled with difficulty in ten villages with very small plots of land owned by the native peasants. ${ }^{16}$ One essential difference, however, between most immigrants and the native peasants was that they possessed rifles, mostly Martinis, which they had retained from when they were in the local militia in Georgia, fighting the Russian armies. As will be dealt with in greater detail below, Çürüksulu Ali Pasha, leader of the Black Sea Georgians, had been the military commander of five militia divisions (tabur) of these native Muslim Georgians during the '93 Harbi'.

In their struggle to survive, the immigrants desperately tried to open pastures and forested land for cultivation, whether or not native peasants or governmental officials consented. Their second solution, banditry, however was far more detrimental to the locals. These immigrants, tough by nature, were already known in their native country, Çürüksu, for their love of firearms. ${ }^{17}$ Now, in their new environment in the Ordu region, they still had their rifles. These firearms soon proved to be vital for their survival under such harsh conditions: brigandage, whether by individuals or bands, notably became commonplace in districts where Georgian immigrants had been settled. ${ }^{18}$

This first serious impact of the arrival of the immigrants in the region was to have its consequences. It destabilized the relative order and security, particularly in the 
countryside where native peasants became the primary target of the bands of brigands. Thus, such banditry by Georgian immigrants throughout the region formed an integral part of everyday life, starting from the arrival of the first immigrant groups and becoming widespread during the 1880 s. $^{19}$

The immediate result of the brigandage by the Georgian gangs was the emergence from the very beginning of tension between the communities in the region. As the activities of such bands increased, tense communal relations turned into resentment, growing gradually into hatred between the Georgians and native communities, both rural and urban. From this mutual hatred would soon emerge what the Ottoman authorities referred to as 'the Georgian problem', ${ }^{20}$ which contributed further to political instability and increasing insecurity, not only in the region of Ordu but throughout the Province of Trabzon.

Another consequence of this problem was the mass emigration of native nonMuslims, mostly peasants from the destabilized countryside, mainly to the Caucasus, then under the Russian administration. From archival documentation, it is understood that immigrant-related brigandage was not the only reason for this migration; in the whole Black Sea region the Russian embassies and their agents were actively encouraging Armenians and Greeks to migrate to Russian territories to replace the Muslim Georgians who had left, in order to repopulate lands left vacant after the war. Whatever the real reasons for their departure, many non-Muslims who left their villages and gave away their lands in Ordu, Giresun and Samsun regions to go to Russia during the 1880 s portrayed themselves as victims of immigrant brigandage, pointing to their harassment by Georgians as almost the only reason for their leaving the region. ${ }^{21}$

It should not be thought that the process of settlement of the Georgian immigrants in the region took its natural course without the involvement of the Ottoman government. It is known from earlier instances of migration that the Ottoman administration attempted to organize the process directly by issuing detailed regulations concerning the settlement of refugees; it established an institutional body, generally called Commission for the Settlement of Immigrants, Iskân- $\iota$ Muhacirin Komisyonu, and appointed officials to run and oversee the settlement process in situ. ${ }^{22}$ However, the situation in the Ordu region was somewhat unusual in that the government and the Commission appear to have appointed Çürüksulu Ali Pasha as the Commissioner for the settlement of the Georgian immigrants. ${ }^{23}$

This naturally gave a greater degree of freedom to the Georgians who had already proved to be extremely difficult for any local authorities to keep under control. Although the details of the initial stages of the settlement process are not known, ${ }^{24}$ numerous cases of stories told by descendants of the immigrants in the region indicate that the process took the form of a quite independent search by the immigrants themselves for suitable land, rather than systematic assignment of plots of land designated by the government. Ali Pasha's appointment as Commissioner obviously facilitated the settlement process following such a pattern. Oral information also suggests that in this process the immigrants themselves were the main actors determining the final choice of lands for settlement, particularly in the countryside. $^{25}$

It should be mentioned that Ali Pasha, as district governor of Ordu, in the early $1860 \mathrm{~s},{ }^{26}$ already knew the area well. By 1879 , he seemed to have already established 
good connections with certain local figures of prominence during both the Crimean War (1853-56) and the war of 1877-78, some of whom had fought against the Russians in the Batum-Çürüksu region as volunteers in local militia troops side by side with native Georgians. During the later part of the Crimean War, these militia troops had been under the command of Ali Pasha - then only a Bey - and his brothers, leaders of the most influential ruling family of the region, the Tavdgiritzes. ${ }^{27}$ Available documentation and the course of events make one seriously consider the possibility that Ali Pasha had already set his mind on Ordu as the final destination for his group of immigrants even during the Berlin peace talks with the Russians in 1878. Therefore, what is seen as the 'accidental arrival' of these Georgian immigrants in the Ordu region was very likely the result of a premeditated plan. In other words, from the very beginning Ali Pasha might well have chosen the region of Ordu as the most suitable home for himself and fellow Georgians from his earlier region of influence in his former homeland. If this were so, the actual process of the settlement of the immigrants in the new homeland under his close guidance and authority as the Commissioner, becomes much clearer: he helped his countrymen to find the most suitable plots for their settlements, solved certain inevitable problems and quarrels concerning property rights arising from the natives, either using his authority or more often manipulating brigand bands, simply allowing them to exhaust the native peasants until they gave up their claims over disputed lands. ${ }^{28}$ This may also largely explain how Ali Pasha used and directed his fellow Georgian immigrants in their new homeland to establish a power base for himself since the widespread Georgian banditry in the region in the 1880s also coincided with such a process of settlement under the direction of the Pasha. ${ }^{29}$

It is important to note at this point that Ali Pasha completed his duty of settling his fellow immigrants in the Ordu district by 1886 and submitted to Istanbul a detailed register containing information on the final situation. ${ }^{30}$ According to this register, the Ordu district with its four sub-districts (nahiyes) saw the settlement of 1,034 immigrant families (or 4,254 individuals) in 26 newly-established villages, most of which emerged on unused lands largely on slopes and in forested plots which were carefully chosen with defence and security concerns in mind more than anything else. Other important criteria for the final choice were the resemblance of the locations to their native villages in Georgia, and, of course, the availability of water resources. ${ }^{31}$ According to the archival documentation at hand, leaving aside those directed and settled in the region west of Sinop, by 1882 around 40,000 Georgian immigrants (individuals not households) were settled in the whole province of Trabzon, some 30,000 of which were in the districts between Ordu and Samsun. Again, some 114 new immigrant villages were created in the same districts. ${ }^{32}$

The level of brigandage was not only significant amongst the ordinary people, but it also became a factor in the political conflict and power struggle between the leaders (rüesa) of the immigrants and the Ottoman authorities, namely the governor of Trabzon Province and his representatives in dependent districts, as well as the judges of the local courts. Inevitably such a struggle involved the established notable Muslim families. It soon extended through the critical branches of the entire provincial administrative system; under Çürüksulu Ali Pasha, the Georgian leadership appears to have used all possible means to get members of their immigrant community into key positions within the civilian, military and fiscal 
administration in the region. It appears that struggle for power and domination, rather than mere survival, determined the main character of this political conflict, as manifest in Ali Pasha's fierce unending battle against the governors of Trabzon throughout the 1880s.

His rivalry particularly with Sirrı Pasha, the capable administrator twice appointed governor of Trabzon Province in the early 1880s, is well documented in all available contemporary sources. Ali Pasha masterfully tried to portray his rivalry with this powerful governor as a story of personal hatred. He did not hesitate to use the presence in the region of his fellow countrymen, the Georgian immigrants, against the governors. He achieved this by directly or indirectly threatening Sirr1 Pasha, by referring to what he saw as 'rumours about so-called Georgian brigandage' in the region. This often meant, and Ali Pasha occasionally spelled it out, that such rumours against the 'poor Georgian immigrants', who were trying to survive in the region under unfavourable conditions, were a severe injustice towards them, and that this was primarily due to the incompetence and mis-administration of the province by the governors. It was on these grounds that Ali Pasha organized constant smear campaigns in the region against the governors who, in the case of Sirrı Pasha in particular, hopelessly tried to re-establish stability in the province, thus discrediting them in the eyes of the local people as well as the Palace in Istanbul. ${ }^{33}$

In the meantime, the waves of banditry continued in such a manner, with ups and downs that the non-Georgian natives and the governors assumed was in fact a masterful orchestration by Ali Pasha himself. According to diverse sources, including reports by foreign consuls in Trabzon, Ali Pasha's manipulation was obvious. Moreover, his personal agenda to become the governor of the province of Trabzon was known, sometimes even made clear in public. Thus, in his manoeuvres, he constantly referred to the "poor innocent Georgian refugees who were loyal to the faith and the state as well as the Sultan under the oppression (zulm) of impotent and prejudiced governors' such as Sirr1 Pasha. On the other hand, he also presented himself as the person who protected them from injustice as well as the only person with the authority to keep them under control whenever some of them, for certain 'unfortunate reasons', were involved in unlawful activities, which in practice usually meant brigandage and corruption. This would also mean that in the province of Trabzon no governor but himself could maintain law and order, and thus bring stability. Ali Pasha was also of the opinion that wherever there were large groups of refugees or immigrants in the Empire, these districts or provinces would be better governed by a respected figure from among the immigrant community; according to Mr Biliotti, British Consul in Trabzon, who had an interview with Ali Pasha in 1884, he was simply defining himself. ${ }^{34}$

The available documentation reveals clearly that Ali Pasha's struggle for power in the province of Trabzon, which constantly brought him into conflict with the governors who were attempting to keep law and order, often resulted in success. One instance is that of Sirrı Pasha, who was twice removed from his position as governor of Trabzon province, each time as a direct consequence of Ali Pasha's campaigns against him. On the other hand, Ali Pasha's political struggle partly failed in that it did not eventually bring him his most desired post: the governorship of Trabzon. It seems that eventually Sultan Abdülhamid II himself found a clever solution to this chronic problem by appointing Sirrı Pasha to a seemingly higher-level governorship 
(in 1884), that of Ankara, and some time later in 1886, promoting Ali Pasha to the position of honorary yâver-i sehriyârî or aide-de-camp, with the title askerîmirliva or Brigadier General which required Ali Pasha to move from Ordu to Istanbul, the capital of the Empire. ${ }^{35}$ However, even with his new title and position, Ali Pasha managed to delay his departure from Ordu for about a year. According to him, he needed to satisfactorily resolve the problem of settling the Georgian immigrants in the region. Let us remember that he was still in the region as iskân memuru or the Commissioner for the settlement of his fellow immigrants.

Nevertheless, it appears that this was not his only reason for staying longer in the region. Some four years earlier, he had divorced his wife, Firuze Hanım, and ever since had been in trouble with a court case she had opened against him in Trabzon and Ordu. He was simply refusing to pay his ex-wife the money (mihr) that she was legally entitled to. This issue was another cause of conflict between Ali Pasha and Sirr Pasha, who initiated the court case and helped Firuze Hanım during the process. If one seeks a factor of personal rivalry between the two men, this court case was perhaps as important as the issue of Georgian immigrants and their widespread brigandage in the region. Ali Pasha's insistence on not complying with the decision of the court (that he should pay the mihr), and Firuze Hanım's determination in taking the issue each time to a higher administrative level, going as far as Yildiz Palace in 1886, seem to have eventually turned Ali Pasha's personal life into an embarrassment for the government. Eventually, in the same year, a special envoy was sent to Ordu and Trabzon to settle this issue. ${ }^{36}$ Thus, Ali Pasha even managed to make his personal issue public, portraying the case to the central government as yet another manifestation of Sirrı Pasha's incurable personal hatred towards him and, most importantly, towards the 'poor Georgian immigrants' under his protection.

After successive orders of warning from the Palace, Ali Pasha was eventually forced to move from Ordu to Istanbul sometime in May 1887. ${ }^{37}$ There was yet another dimension to the politics of immigration, which went hand in hand with Ali Pasha's presence in the region as leader of the Georgian immigrants, mostly in rivalry with the governors. Archival and oral sources both indicate that, under the protection and perhaps encouragement of Ali Pasha, now in Istanbul in the close circle of yâverân at Yildız Palace, prominent members of the younger generation of Georgian settlers from notable families (hânedan or rüesa) continued the power struggle against the Muslim notables of the Ordu region (including Fatsa) in the 1890s. As previously mentioned, this region like many other parts of the Eastern Black Sea region, which roughly corresponded to the Province of Trabzon, also had several long established powerful notable Muslim families; as big landholders, they were part of the emerging trade bourgeoisie, and the de facto power in almost all spheres of public life and local administration. ${ }^{38}$ Most available arable lands, pastures and forests from the coasts, along the valleys and up onto the high plateaus, where native Muslims and non-Muslims regularly spent the summer, were owned by these Muslim landlords. They also held significant administrative posts, and exerted enormous influence over the judicial administration. Katırcizades, Felekzades, Şeyhzades in Ordu for instance dominated the mayorship and other positions in local councils throughout the period in question. ${ }^{39}$

With the arrival of Georgian immigrants in the region, the Georgian nobility attempted to establish itself as a power, based on their fellow immigrant community, 
challenging the local Muslim nobility. After Ali Pasha's move to Istanbul, this struggle further tried the inter-communal relations already strained by the banditry. As political struggle gradually increased at local level, new leaders such as Bacinzade İbrahim Efendi and Çoloğlu Hasan Ağa developed their forces to a stage where hundreds of armed Georgians, experienced in guerrilla warfare from the previous war, entered into open clashes with the native Muslim notables. It seems that the 'Georgian question' supported by banditry had given rise to a reaction on the part of the natives, who also produced hundreds of armed men under their a $\breve{g} a$ s and beys. Thus, the 1890s appears to be a period during which the 'mutual hatred' (sources often use the phrase 'Gürcü-Türk Münâfereti') between the two communities was consolidated, building up to the most violent armed conflicts. This local warfare in the district of Ordu could only be stopped with great difficulty, through direct intervention by the Istanbul government that sent the leaders of both sides into exile in the first years of the twentieth century. ${ }^{40}$ Only then was there a return to a relatively peaceful era of reconciliation under the efforts and close scrutiny of the authorities; as advised, some of the leaders of rival families, on return from exile, intermarried to seal a permanent peace. $^{41}$

Of no less significance, another dimension of the politics of immigration in the province of Trabzon assumed the form of continuous attempts by the local elites, both officials and notables, to influence what appeared to be the constant debate on the reorganization of administrative units in Ottoman provincial administration in their regions. Following the Tanzimat rule's major attempt to create a modern hierarchical administrative order by the Acts of Provincial Administration (Vilayet Nizamnamesi) of 1864 and 1867, sub-province (sancak) and district (kaza) units were also reshuffled in the province of Trabzon. Since Trabzon formed the north-eastern border of the Ottoman Empire, the loss of the greater portion of the Sancak of Lazistan, including the districts of Batum and Çürüksu, to Russia under the Treaty of Berlin in 1878 had a direct impact on the administrative organization of the region. Transportation problems, particularly lack of roads connecting sub-districts with centres, created enormous difficulties and made legal administration and maintenance of security along the eastern border practically impossible, also negatively affecting the everyday routine of the populace.

The arrival of thousands of immigrants and their settlement particularly in the area between Ordu and Samsun further exacerbated such difficulties, and revived the debate over the borders of the local administrative units, whose organization was based on multiple concerns ranging from potential financial sources (i.e. tax revenue), economic development and the volume of trade (through an efficient port for sea trade and transportation) to public security, settlement patterns and population, transportation facilities and roads, physical distance between administrative centres, topography and landscape, and the like. ${ }^{42}$

The Georgian immigrants first entered the debate through the rapid rise and spread of banditry, which in the eyes of the natives and the governmental authorities became a synonym for the newcomers. Its direct consequence on public security resulted in increasing concerns on behalf of local administration. In the absence of proper roads and equally distant from both sancak centres, Trabzon and Samsun, the region of Ordu was eventually left ungovernable and insecure, with remarkably few police officials in the region. For more effective government with more financial, 
military and police resources and administrative means, the Ordu district should have been separated from Trabzon and merged with the Fatsa and Ünye districts of Samsun as an independent sanjak. In this respect, the issue of Georgian immigrants and security was clearly mentioned as a significant factor in the letters and telegrams from locals to Istanbul, demanding urgent reconsideration of the administrative borders. $^{43}$

The situation was further complicated by Ali Pasha's struggle for power and his personal agenda, becoming the governor general (vali) of the province of Trabzon, and making his brother Osman Pasha the governor (mutasarrif) of the future sancak of Ordu (if not, to Canik). ${ }^{44}$ The administrative borders debate soon turned into a discussion of which town should have been, or deserved to become, the administrative centre of the new sancak: Fatsa, Ünye, or Vona (modern Perşembe); Ordu, being too close to the eastern border, was not considered. Particularly in the years between 1883 and 1885, local influential figures of these towns entered into a singular race to present to Istanbul their particular case with as convincing an argumentation as possible. Again basing himself in the Georgian immigrant community in the area and using his contacts in Istanbul, Ali Pasha seems to have adhered through his own local associates to Vona, where he and his family happened to be settled. Their argumentation was that this small coastal town, or rather village, had the largest natural bay on the whole Black Sea coast, most suitable for development as an economic and military centre; to many locals, this seemed bizarre and unrealistic, even farcical. His second choice appeared to be Fatsa, which also had a sizeable Georgian immigrant community; the advantage of this town was its geographical centrality, compared to Vona, too close to Ordu, and Ünye, the westernmost district of the proposed sancak.

A rather silent agreement between the Georgians and the native locals on the necessity for the creation of a new sancak in the region, but for different reasons, was also observed. For the native nobility and trade bourgeoisie (both Muslim and nonMuslim), one of the most important reasons was to deal better with the increasing banditry that was associated with the Georgian immigrants. They were also concerned with the future economic development of their own region, and, for that matter, even ready to support Ali Pasha's undeclared candidacy to the governorship, thinking quite reasonably that the Pasha's close contacts with Istanbul might well be beneficial to their interests. ${ }^{45}$ For Ali Pasha, his close Georgian associates and the whole immigrant community, on the other hand, the prime purpose was Ali Pasha's becoming governor of the entire province of Trabzon (the best option), or at least governor of the new sancak where the Georgian immigrants were most densely settled, from Ordu to Ünye. It seems that everything, including the even distribution of the immigrant population under the Commissariat of Ali Pasha, was cleverly designed by the Pasha himself in his premeditated goal of establishing himself as the key power in his new 'home'. As already referred to above, the British Consul of the time in Trabzon, Mr Biliotti, already seemed convinced of this. Even the increase and rapid spread of Georgian banditry from the very early days of their arrival onwards had, to Biliotti, direct relevance to the same plan. Ali Pasha was personally manipulating his fellow Georgians and their unlawful activities to extremes so that he could put pressure on Istanbul, eventually persuading the government that the only logical and practical solution to the increasing security problem and the 
apparent 'maladministration' in Trabzon Province would be to entrust the governorship to the capable hands of a person such as himself.

Did all this eventually yield the desired result? The answer is clear: No! In the 1880s, Ordu was not made a separate sancak, nor was Ali Pasha appointed governor general to Trabzon, as already noted above. However, the legacy of such a dangerous and costly struggle for the highest administrative positions at the local level in the province was strongly felt in the decades that followed, in terms not only of lives and property lost as a result of increasing banditry and armed clashes, but also the mutual hatred that had built up between the natives and the immigrant Georgian communities. Even in the 1920s, in the parliamentary discussions in Ankara, the 'Georgian Problem' and the security issues closely associated with it were still on the agenda when administrative units in the region were once more hotly debated among the MPs in the National Assembly in Ankara. ${ }^{46}$

Ali Pasha, who appeared to be so closely associated with the perpetrators of widespread Georgian banditry in the region throughout the 1880s, was also a military man. As the leading figure of a family of local rulers in the area of Çürüksu in particular under the Ottomans, he had always served, from the Crimean War onwards, as the commander of local militia troops of asker-i muavine, fighting actively against the Russian armies. ${ }^{47}$ The local Georgians of this borderland with the Russian Empire were in a sense natural warriors who, under their local chiefs, developed a regional system of border defence not always in complete harmony with either Ottoman or Russian imperial administrations; the border was rather fluid and flexible. It was not uncommon for its people to find themselves in a state of precarious freedom. Even in times of peace crossing the river-cum-border to escape taxation or interrogation for a criminal act was commonplace. ${ }^{48}$

Since the Crimean War, members of the Tavdgiritze family, Ali Pasha and his brothers, no longer ruled the area; now there was a district governor or kaymakam appointed by the Ottoman administration. However, it seems that one of the brothers often held that position too. It is not difficult to understand therefore that the family maintained de facto power, still assuming, whether officially or voluntarily, the duty of border defence with the local chiefs under their influence. ${ }^{49}$ Furthermore, the family was also at the centre of a lucrative slave trade business between the region and Istanbul. Part of this activity involved regular attacks on neighbouring regions for ransom, slavery or kidnapping young girls to be eventually sold to the families of the ruling elite in Istanbul. ${ }^{50}$

Ali Pasha's background was thus one of being a local 'hero' in the eyes of the Ottoman centre and the men he worked with closely. Yet for those who fell victim in one way or another to his aggression and unlawful activities, he was the 'chief bandit' of his region. There is abundant evidence of his 'criminal' acts as reflected in Ottoman archival documentation, well before the 1877-78 war, from which he once more emerged as a prominent figure of a very mixed nature. Along with the Ottoman regular army stationed in Batum during the war, the Pasha as a mirimiran (title bestowed by the Ottoman Sultans to figures of prominence from among local nobility, hanedan) formed again his militia of five troops, composed essentially of local Georgians but also including volunteers from the Black Sea districts of Anatolia. ${ }^{51}$ At the beginning of the war, his troops performed outstandingly against the Russian army's offence, defending the mountainous front lines of the Ottoman 
Empire in the region. The Pasha was immediately granted the title of militia commander of mirliva, although he insistently and personally asked for the rank of military (=askeri) mirliva. However, a short time later inconsistent and independent manoeuvres of his troops cost the Ottoman defence dearly in the Batum-Çürüksu front. In the meantime, rumours about Ali Pasha's secret treasonable relations with the Russians became the main topic of the correspondences exchanged between the Ottoman army command in Batum and the military headquarters and the Palace in Istanbul. $^{52}$

Once Ali Pasha's presence as commander of the muavine troops on the war front was considered harmful, he was immediately called to Istanbul in the middle of the war; in his absence, from then until the end of the war, his brother, Osman Pasha, acted as commander of the troops. Controversy about Ali Pasha continued even after he left; letters and telegrams from both locals and members of the military kept flowing to Istanbul asking the government not to let the Pasha return to the region. Although some of his men and close associates would always stand by him, his general popularity in the Batum-Çürüksu area appears to have declined significantly.

When the war was eventually settled with the signature of the Treaty of Berlin in 1878 , the Ottoman government decided on the situation of the Muslim populations of the region ceded to Russia; it seems that Ali Pasha was directly involved in this process in Istanbul. Using his contacts and influence at a distance, he also played a crucial role in persuading the Muslim Georgians to emigrate to Anatolia at a time when they were seriously divided among themselves on the issue. ${ }^{53}$ Having kept the Russian forces outside the Batum region throughout the war, Ali Pasha's men strongly resisted the idea of leaving their homeland to Russia, and refused to hand over their arms to the Ottoman military leadership in Batum. All available documentation points to the fact that Ali Pasha's involvement eventually persuaded them to collaborate and start making preparations for the move to new lands in Ottoman Anatolia. ${ }^{54}$

This is how a great portion of the Muslim Georgians left their homelands and emigrated to Turkey en masse. The critical point at this juncture was the fact that Ali Pasha appeared to have managed, most probably through his brother Osman Pasha, ${ }^{55}$ to keep his close associates, local chiefs and their families together even during the migration, which 'accidentally' ended up in the region of Ordu. Another significant point is that Ali Pasha must have also moved at to the region from Istanbul about the same time, ${ }^{56}$ settling down, quite expectedly it seems, with land and houses both in Vona and the city of Ordu, where a portion of his closest associates, well-off prominent figures, also happened to choose to settle.

From that moment on, as previously mentioned, the Pasha began very carefully to form a power base, securing firm ground for himself as Commissioner by directly arranging and facilitating the settlement of his fellow immigrants in the area between Ordu and Ünye. He spent the following years until 1887 in the towns of Ordu and Vona where he soon accumulated great wealth, including a number of houses and large tracts of lands, while acting as iskan memuru and waging a fierce war against all appointed governors to the province, as outlined above.

As for the legacy of the muavine troops that he had commanded during the previous war, it is interesting to note that Ali Pasha continued to use his 'military' 
experience, or rather to remind everyone, both natives and the Palace in Istanbul, that he was still a man of might with the utmost loyalty to the Sultan. Twice in his new home, first in 1881, when he was bestowed the first degree Imperial Medal, Mecidiye, and again in 1886, during the war on the Western front against the Greeks and Bulgarians, he openly wrote to the Sultan that he was always ready with thousands of militiamen under his command to serve wherever the Sultan wished him to fight against the enemies of the Empire. While in the first instance he mentioned 4-5,000 men, ${ }^{57}$ in the latter he went further by composing a register which carefully recorded the names (with patronyms) of all those who would hold positions of ranks up to militia binbass or Major of an army of over 10,000 men (10,106 to be precise, forming four regiments or alays) from the districts of Ordu, Fatsa and Ünye, overwhelmingly consisting of immigrant Georgians. In this offer of service to the Sultan, he emphasized his loyalty and the readiness of his troops to sacrifice themselves for the state, the nation and Islam. ${ }^{58}$ Though he might have been pleased with the vigour and loyalty of his Pasha, the reigning Sultan, Abdülhamid II, seemed uninterested in the offer. What is important, however, is that shortly after the presentation of his register to the Palace, Ali Pasha was made honorary aide-de-camp or fahri yaver for the Sultan and called to Istanbul. This time, the Pasha was finally granted the rank of 'military' mirliva, which he had so longed for.

This new position and the title must obviously have honoured Ali Pasha. After all, he had reached one of his ultimate goals, becoming a member of the military proper as a Brigadier General, which brought significant rewards in both prestige and financial terms. One may argue that, on top of all this, he would still have wished to see himself as Governor of Trabzon, in which he had over the years vested so much personal interest. All this clearly reveals how serious and committed Ali Pasha was in materializing his personal desires and how potentially dangerous he could become in local politics over a period of less than a decade in his new home in the Province of Trabzon. The impressive size of the army that he stated he could form in the districts around Ordu alone might have irritated the Sultan, indicating the destructive potential of such a big military force in a region where fierce power politics dangerously involved the immigrant community.

Although the Pasha's proposed army also included some non-Georgian natives of the region, some of whom were to become prominent names in the $1890 \mathrm{~s}$ as leaders of the rival Turkish factions in the all-out armed conflict between the two communities, further militarization of the local population must have been considered by the Palace a serious threat to an already unstable part of the Empire. It is not totally unreasonable to think, therefore, that it was this danger more than anything that decided the Palace to finally intervene in the local power politics, finding the solution in moving the person at the very centre of the problems away from this delicate region, with the chronic issue of Georgian immigrants.

Ali Pasha's move to Istanbul in 1887 might have eliminated the immediate danger of such a big militia army in the region. However, this move was obviously neither sufficient nor early enough to prevent the Palace's most feared result. The violent inter-communal conflicts that eventually broke out in Ordu in the 1890s continued into the early years of the twentieth century. This 'war' between the two communities involved hundreds of armed men in a struggle between local notables wanting 
domination over the region. One may well argue that this was an inevitable consequence of the power politics that had escalated from banditry and the culture of militia warfare with a long history behind it.

This study has focused on certain personal motives of central figures of the Georgian immigrant community, in an attempt to understand their ambitions within the complex framework of the struggle of newcomers settling into a region with a long established local nobility. However while it is understandable that the immigrants fought for a legitimate right to survive, their leader was aiming higher, for domination. The above detailed analysis may not be a unique case; it could be indicative of aspects that might be found beyond the Georgian immigrants that settled in this particular region. The pattern observed in this case may well apply, with certain variations in detail and in scope, to many other immigrant groups who arrived in Anatolia under the most difficult and challenging conditions in the final period of the Ottoman Empire.

Certain characteristics seem likely to appear in any study of this kind on individual immigrant cases. Firstly, immigration stories would tell us primarily about a struggle for survival more than anything else. Whether the story of an individual or that of a group of immigrants, irrespective of how closely the migration and settlement processes followed central administrative plans, the lives of immigrants in their new homes always required extraordinary efforts to reduce perceived threats. In this case, for example, no one could have foreseen the severe drought and ensuing famine that happened to coincide with their arrival in Anatolia. Similarly, the governmental rules and regulations regarding the responsibilities of the native population may not always have guaranteed a warm welcome to immigrants. Even exemptions from taxes and military service may well have been seen as irrelevant by an immigrant still without shelter or land, so essential to survival. Also, lands offered to certain immigrants may have been unsuitable for cultivation; harsh climatic conditions might have rendered settlement even more challenging. Or, as in the case of these Georgian immigrants, the incomers may not have appreciated what was being offered to them in their new environment, thus becoming such a nuisance for the natives that the positions of oppressor and villain might have quickly been reversed. Such a reversal may not seem so incomprehensible when a more general picture of the lives and extreme conditions affecting every single life, native and newcomer alike, all lives reduced to precarious existence. These are also moments when the most violent traits of human nature would easily become manifest.

The combination of historical accident and natural calamity were obviously at play in this case; the Georgian immigrants landing unexpectedly on the natives during a period of drought and famine. While this case may differ from others in the personal political agenda of the leadership, the Ali Pasha factor, the tough character of the immigrants, combined with their wartime experience and their probable ownership of firearms on arrival, immediately bring to mind the other Caucasian immigrant groups, namely the Circassians, who had also caused similar problems in their respective areas of settlements all over Anatolia, and particularly well documented for the region of Uzunyayla. ${ }^{59}$ 
The peculiarity of our case appears to lie in the Ali Pasha factor, where one individual is now seen to have planned, long before the actual migration process, a final destination that the Ottoman government would not have approved. This example illustrates the overlap between instinctive survival strategies and sociocultural habits of the immigrants and the personal political agenda of their Pasha. This amalgam also included, and, as noted above, directly linked the peculiarities of the Ottoman administration in the Caucasian borderland of Çürüksu region and intricacies of the imperial elite in Istanbul as well as the Palace itself, ${ }^{60}$ as Ali Pasha's personal rise from provincial nobility to imperial elite in the close vicinity of the Sultan. His fluctuating fame seems to have followed him closely from the beginning of his provincial career to the end; he was as canny and manipulative in 1887 when he moved to Istanbul as a yaver to the sultan with a high military rank as he had been in the 1860 s when he took his first steps in Çürüksu region towards his career in the imperial household.

The most critical moment in this journey appears to be the 1877-78 war years, and the ensuing period of migration and settlement of his fellow Georgians to Ordu up to 1887. While the Pasha's manipulative skills and opportunistic mind took him to personal fortune, it is equally arguable that his fellow immigrants, the Georgians, largely owed their successful hold on and survival in the region of Ordu to their Pasha's vigorous political manoeuvres in pursuing his goals at all cost while also protecting his men against the odds. Their Pasha's appointment as Commissioner for their settlement gave these muhacirs relative freedom to search for the most suitable plots of lands, shielding them from complaints another Commissioner might have received about the relatively large size of their groups, or their excessive violence.

At this point, one should perhaps direct attention to James Reid's analysis of various forms of internal conflicts in nineteenth-century Ottoman society, which highlights the inability of the Ottoman imperial administration to regulate social differentiations and disturbances through legal means, often resulting in factionalism within the wider society. Further fanning of existing feuds and aroused vendetta culture among certain groups contributed significantly to the consolidation of authoritarianism of the state, intent on keeping order. Reid cites cases of Circassian immigrants who brought their feuds into the Ottoman Empire, and points to similar customs among the Kurds and Lazis, a group that also includes the Georgians. ${ }^{61}$ Reid's analysis may be useful in explaining in part the situation of the Georgian immigrants dealt with in the present study.

Even more illuminating in our case is Reid's concept of "uncontrollable "loyal" chieftains' to describe those semi-autonomous authorities, local notables who theoretically gave obedience and allegiance to the Ottoman state, but in fact acted quite independently, as individuals or oligarchies. In this, Reid refers exactly to individuals like Ali Pasha, and their armies composed of irregulars who may have served the state in times of war but in post-war periods posed a serious threat to local security and order, still able to be 'disloyal' as and when they wished. Furthermore, the system of intisab or group solidarity pact among male relatives of a clan meant that a faction could seek to place their members or clients/allies in offices and positions at any level of the bureaucracy or army command structure, thereby eventually forming an extended network. ${ }^{62}$ 
Reid's analysis of the existence throughout the nineteenth century of such enclaves of precarious freedom of action for certain groups at certain localities in the vast territorial space of the Ottoman Empire, often extremely difficult to rule and control, may well explain the case with which we are confronted here. Ali Pasha's recurrent expressions of 'loyalty' to the Sultan, religion and the state may, therefore, be seen as much as rhetoric as a manifestation of a certain reality, where loyalty is seen to assume a dual nature. Yet it seems that it obviously had its symbolic power when used in the appropriate political climate and with the help of the proper functioning of the empire-wide clientèle network, to raise him to the imperial household under Abdülhamid II, the sultan who obsessively created his own world of symbolism within and outside the Empire, irrespective of the degree of relevance of this world of symbols to the real world. ${ }^{63}$

Returning to the Georgian migration and Ali Pasha's central role in the ensuing struggle for power, the native nobility is seen to be as oppressive as Ali Pasha in terms of their dominance over native peasants, predisposing them to rivalry in the fight for eventual domination in the region. They also struggled to maintain their own power in their long-established locality, through large scale landownership with its population of dependent peasantry. ${ }^{64}$ The arrival of the Georgian immigrants in their area was the greatest challenge to their power that they seem to have ever encountered until then. It is clear that Ali Pasha was careful to avoid direct confrontation, and at times even tried to make alliances with the local nobility, which had pre-Tanzimat connections of ayanhood; rather, he targeted provincial governors and administrative authorities in pursuing primarily his personal goals. Ali Pasha's successors as leaders of the Georgian immigrant community (rüesa-i muhacirin) in the 1890 s proved to be politically much less talented; more in tune with their 'natural' habits, and ways of doing things in their former homeland, they eventually turned the entire region into a battleground for over a decade. It seems that Ali Pasha's successors in the region developed their own agenda along different lines, pursuing territorial expansion to establish themselves as a landed aristocracy through enlargements of lands in rural areas. This most concrete basis allowed them to exert their influence to the detriment of the power of the native landholding nobility. While one may think that the violence changed nature in parallel to this major shift in the core of the conflict, from a political to an economic one, or similarly, from much more sophisticated ways of struggle for power to a more direct use of violence.

As for the situation of the ordinary inhabitants and peasants of the region, Muslims and non-Muslims, including the ordinary Georgian immigrants who tried to stay as much as possible outside of all this, their little known story remains to be written. Other than their occasional unwilling involvement in these power games, stories of folk heroes such as Hekimoğlu and Soytarığlu, who emerged as bandits fighting against the oppression of the Georgians in their regions, certainly have some truth in them. ${ }^{65}$ However, these are not enough to satisfy historians seeking a more comprehensive picture of the complex realities of the period. More archival research and more field studies, including oral history work, are needed to develop a reliable and fuller understanding of migrations in general and the power politics that seem inevitably to have ensued. 


\section{Notes}

This study is an extended version of a paper presented at the international conference on 'OttomanRussian War of 1877-1878 (93 Harbi)' held at the Middle East Technical University, organized by the Department of History, 2005, Ankara, Turkey. Based on the preliminary results of an ongoing project towards a detailed volume, the essay attempts to reconstruct a case of immigration within the context of local power politics in late Ottoman history. The author is grateful to Kaan Durukan, Mark Soileau, Muhsin Soyudoğan and Claire Özel for their valuable comments and suggestions.

1. To cite a few, see K.H. Karpat, Ottoman Population, 1830-1914: Demographic and Social Characteristics (Madison, WI: The University of Wisconsin Press, 1985); K.H. Karpat, The Turks of Bulgaria: The History, Culture and Political Fate of a Minority (İstanbul: The Isis Press 1990); J. McCarthy, Death and Exile: Ethnic Cleansing of the Ottoman Muslims, 1821-1922 (Washington: Darwin Press, 1995); N. İpek, Rumeli'den Anadolu'ya Türk Göcleri (1877-1890) (Ankara: TTK Basımevi, 1994); N. İpek, Imparatorluktan Ulus Devlete Göscler, Trabzon: Serander Yay., 2006; A. Halaçoğlu, Balkan Harbi Sırasında Rumeli'den Türk Gösleri (1912-1913) (Ankara: TTK Basımevi, 1994); H. Şimşek, Türk-Bulgar İlişkileri ve Göc (İstanbul: Harb Akademileri Yay., 1999); Y. Ağanoğlu, Osmanlı' dan Cumhuriyet'e Balkanların Makus Talihi (Göc) (İstanbul: Kum Saati Yay., 2001); F. Dündar, Ittihat ve Terakki'nin Müslümanları İskan Politikası (İstanbul: İletişim Yay., 2001). For the migrations from the Caucasus, see H. Bice, Kafkasya'dan Anadolu'ya Göcler (Ankara: TDV Yay., 1991); B. Habicioğlu, Kafkasya'dan Anadolu'ya Göscler (İstanbul, Acar Matbaacılık, 1993); A. Saydam, Kırım ve Kafkas Gösleri (1856-1876) (Ankara: TTK Basımevi, 1997).

2. The exact number of Georgians emigrated to Ottoman Turkey is not known since no systematic and reliable record is found in the archives; the available figures from different sources are mentioned below.

3. This story is commonly known in the region, even among the third generation immigrants with whom I have conducted interviews over the past five years.

4. Public Record Office, London, UK (hereafter PRO), FO 195/1329, report No.2, dated 30 June 1880.

5. Article 21 of the Treaty of San Stefano (Yeşilköy) (5 March 1878) regulates and allows migratory movements during a three year period of time following the signature of the treaty. The Treaty of Berlin (13 July 1878) however does not have a specific article for a general migration but refers to migration separately for each cases of Serbia, Bulgaria, Romania, etc. See N. Erim, Devletlerarast Hukuku ve Siyasi Tarih Metinleri, Cilt 1 (Osmanl Imparatorluğu Anlaşmaları) (Ankara: TTK Basımevi, 1953), pp.373-427.

6. Ministère des Affaires étrangères, Paris, French Consular Report (hereafter AE, CE), Trebizonde, 1876-1880, No.264. I am grateful to my colleague Dr Alexandre Toumarkine for kindly sharing with me the documentation from French Foreign Office Archive in Paris.

7. PRO, FO 195/1831.

8. See PRO, FO 195/1420. For a discussion of the total number of Georgian immigrants from the region, see M.A. Toumarkine, 'Entre empire ottoman et état-nation Turc: Les immigrés musulmans du Caucase et des Balkans du millieu du xixè siècle à nos jour' (Unpublished Ph.D. Dissertation, Université de Paris IV, Sorbonne, 2000), Vol.1, pp.136-140. The Georgian newspapers of the time, Droeba (No.73), and Shroma (No.40), confirm the number $(80,000)$ of the immigrants that had already left by 1882 , whereas 140,000 were waiting to leave. According to the same sources, 60,000 Georgians decided to stay, not leaving their lands. See T. Megrelidze, Acaris Tsarsulidan (Muhaciroba 1878-1882 Tslebsi) (Tbilisi: Metsniereba 1964), p.154.

9. According to the last Ottoman population records for the region that comprises the districts where the Muslim Georgians constituted the overwhelming majority (75,612 males), including Batum and Çürüksu, there was a population of 77, 823 males (or 38,933 households) in 1877. See K. Emiroğlu (ed.), Trabzon Vilayeti Salnamesi, 1878, vol.10 (Ankara Trabzon İli ve İlçeleri Eğitim, Kültür ve Sosyal Yardımlaşma Vakfı Yayınları, 1999), p.241. However, as has always been the case, some people might have evaded the survey. Considering the conventional assumption that adult males formed onethird of the total population in pre-industrial societies, or the average size of a Georgian household of the time (according to some sporadic figures recorded in Ottoman documentation) was 5 to 6 individuals, one may estimate a total population of around 200-250,000 in the original lands of the immigrants from the whole region before the war. We know that some Muslims, though insignificant 
in number, remained in their villages and did not migrate to Anatolia while some immigrants returned after a short period. Therefore, a reasonable estimate of the total immigrant population would be between 150,000 and 200,000 individuals by 1883 . Georgian studies conducted in the 1890 s in the region also point to the same numbers concerning the total population of Georgian immigrants during the same period. See Z. Chichinadze, Kartvel Mahmadiant Gadasahleba Osmaletsi - Muhaciri Emigratsia (Tbilisi: Kereselidze Press, 1912), p.63, and passim; Compare Megrelidze, Acaris Tsarsulidan, pp.148, 154-5. I thank Mr Irakli Koplatadze and Fahrettin Çiloğlu for providing me with these figures and translating sources from Georgian.

10. See the works cited in note 1 above.

11. The situation of the locals was even worse in the neighbouring district of Giresun, according to British Consular reports. PRO, FO 195/1329.

12. O. Özel, 'Muhacirler, Yerliler ve Gayrimüslimler: Osmanlı' nın Son Devrinde Orta Karadeniz'de Toplumsal Uyumun Sinırları Üzerine Bazı Gözlemler', Tarih ve Toplum Yeni Yaklassımlar, Vol.5 (2007), pp.93-112.

13. Ibid., p.95.

14. See the works cited in note 1 for such responsibilities assigned to native populations usually referred to in the Ottoman documentation as ahali-i kadime. Kemal Karpat points to the early Islamic origin of such an obligation as the duty of Muslims by reference to the migration or hijra of Prophet Muhammed and his followers from Mecca to Medina where they were warmly welcomed by the inhabitants of the city. See K. Karpat, 'The Hijra from Russia and the Balkans: The Process of SelfDefinition in the Late Ottoman State', in D. Eickelman and J. Piscatori (eds.), Muslim Travellers (London: Routledge, 1990). I thank Dr Kaan Durukan for drawing my attention to this work.

15. PRO, FO 195/1381, report of the British Consul at Trabzon dated 4 May 1881. Also see FO 195/1457, report dated 10 May 1883; Başbakanlık Osmanlı Arşivi, İstanbul, Turkey (hereafter BOA), DH.MKT $1468 / 48,1468 / 71,1474 / 26$.

16. PRO, FO 195/1329, Report No.12.

17. Chichinadze, Kartvel Mahmadiant Gadasahleba Osmaletsi, pp.121-2.

18. It must be mentioned that the banditry had long been widespread in Anatolia since the Celali violence of the seventeenth century. For a work dealing with the banditry in the surrounding regions during the eighteenth and nineteenth centuries, see M.Y. Erler, 'Trabzon Vilayetinde Kanun Kaçakları', Ankara Üniversitesi Dil ve Tarih Coğrafya Fakültesi Tarih Arastımaları Dergisi, Vol.30 (1997), pp.69-98.

19. BOA, A.MKT.UM 428/15, 456/84, 506/95, 998/29; A.MKT.MHM 418/38, 426/1; A.MKT.UM 476/ 66, 477/6). Compare PRO, FO 195/1457, report dated 10 May 1883; FO 195/1488, report nos. 3 and 38 .

20. BOA, DH.MKT 471/70.

21. See Özel, 'Muhacirler, Yerliler ve Gayrimüslimler'.

22. For the establishment of this institution and its early development, see D.C. Cuthell Jr., 'The Muhacirin Komisyonu: An Agent in the Transformation of Anatolia, 1860-1866' (Unpublished Ph.D. Dissertation, Columbia University, 2005).

23. BOA, ŞD, Trabzon: 1835/14; İrade, Dahiliye: 79703.

24. This might be partly because the Commissioner in our case was Ali Pasha himself. It is highly likely that he managed the whole process as quietly as possible by using his authority over the local officials with minimal correspondence with the headquarters of the Muhacirin Komisyonu in Istanbul and the Ottoman government.

25. Compare Megrelidze, Acaris Tsarsulidan, p. 155, where the author refers to the case of those who were secretly leaving for Turkish Black Sea region to search for suitable land, and stayed only if they liked it; otherwise they returned, again secretly, to their homes in Georgia and were not always able to find their houses.

26. See F. Millingen, 'The Circassian Slaves and the Sultan's Harem', Journal of the Anthropological Society of London, Vol.8 (1870-71), p.cx.

27. See A.R. Trabzoni, Manzume-i Sivastopol, ed. Veysel Usta (Ankara: Kültür Bakanlığı, 2000).

28. PRO, FO 195/1457, despatch dated May 1883.

29. PRO, FO 195/1457, despatch dated May 1883. Compare S. Paşa, Mektubât, Nutuk ve Makalât, manuscript: 06. MK. Yz. A 6884, Milli Kütüphane, Ankara, n.d., 200.

30. BOA, İrade Dahiliye, 79703.

31. All oral information gathered in the region also point to these factors. 
32. The numbers are as follows (in districts): Ordu (26 villages), Samsun (12 villages), Fatsa (20 villages), Ünye (42 villages), Terme (5 villages) and Çarşamba ( 9 villages). In the area east of Ordu up to Hopa, it appears that much lesser numbers of immigrants were settled individually in towns and cities only. See B. Yildiz, 'Emigration from the Russian Empire to the Ottoman Empire: an analysis in the Light of New Archival Material' (Unpublished MA thesis, Bilkent University, 2006).

33. For this rivalry, see O. Özel, 'Women, Justice and Power in the Late Ottoman Society: the Story of Firûze Hanım' (İstanbul: The Isis Press, forthcoming). Compare H. Özdiş, 'Taşrada İktidar Mücadelesi: II. Abdülhamid Döneminde Trabzon Vilayeti’nde Eşraf, Siyaset ve Devlet (1876-1909)' (Unpublished Ph.D. thesis, Hacettepe University, 2008), Chapters II and IV.

34. PRO, FO 195/1457, and 1488 (in this, see particularly despatches nos. 33, 37, 38, 39, and 40).

35. BOA, ID 998/78850.

36. BOA, Y.PRK.MYD 6/38. For details, see Özel, 'Women, Justice and Power in the Late Ottoman Society'.

37. BOA, Y.A. Hus 202/72; 203/8.

38. M. Meeker, A Nation of Empire. The Ottoman Legacy of Turkish Modernity (Berkeley: University of California Press, 2002).

39. S. Çebi, Ordu Sehri Hakkında Derlemeler ve Hatıralar (Ordu: ORSEV Yayınları, 2000).

40. Ibid., pp.160-164.

41. See O. Özel, 'Çürüksulu Ali Paşa ve Ailesi Üzerine Biyografik Notlar', Kebikę̧, Vol.16 (2003), pp.95-144.

42. See Özdiş, 'Taşrada İktidar Mücadelesi', esp. Chapters II and IV.

43. BOA, ŞD $1837 / 9$.

44. BOA, HR.TO 260/104.

45. Özdiş, 'Taşrada İktidar Mücadelesi', pp.210-11.

46. Çebi, Ordu Sehri Hakkında Derlemeler ve Hatıralar, pp.243-74. Compare TBMM Gizli Celse Zabıtları, Vol.2 (İstanbul: Türkiye İş Bankası Yayınları, 1985), pp.284-5.

47. These local armies of irregulars were a common feature of the whole region of Southern Caucasia and they were known for their heroic fights against the Russian military advance in their regions throughout the nineteenth century. See Toumarkine, 'Entre empire ottoman et étatnation Turc, Vol.1, pp.65-68, 70-72. For a very useful study of the Ottoman military organization with a particular attention to such irregular armies during the Tanzimat period, see J.J. Reid, Crisis of the Ottoman Empire, Prelude to Collapse, 1839-1878 (Stuttgart: Franz Steiner Verlag, 2000).

48. For the region under Ottoman rule, see B. Kodaman and N. İpek, 'Çürüksu Kazası', Ondokuzmayls Üniversitesi Ĕgitim Fakültesi Dergisi, Say1 7 (1992, pp. 99-120). For a useful overview of the general social characteristics of the region under Ottoman rule, see Toumarkine, 'Entre empire ottoman et état-nation Turc', Vol.1, Chapter 1, esp. pp.52-63.

49. Compare Toumarkine, 'Entre empire ottoman et état-nation Turc', Vol.1, p.66.

50. Millingen, 'The Circassian Slaves and the Sultan's Harem'; cf. Toumarkine, 'Entre empire ottoman et état-nation Turc', pp.109-10.

51. G. Başkanlı̆̆ı, Türk Silahlı Kuvvetleri Tarihi. Osmanlı Devri 1877-1878 Osmanlı Rus Harbi Kafkas Cephesi Harekâtı, II. Cilt (Ankara: Genelkurmay Basımevi, 1985). See also D. Gillard (ed.), British Documents of Foreign Affairs: Reports and Papers from the Foreign Office Confidential Print, Part I, Series B, The Near and Middle East, 1856-1914, Vol. 4, The Ottoman Empire and the War with Russia, 1877-1878 (Frederick, MD: University Publications of America, 1984), pp.118-32, and La guerre d'Orient en 1877-1878; étude stratégique et tactique des opérations des armées russe et turque en Europe, en Asie et sur les côtes de la mer Noire, par un tacticien ... Ouvrage rédigé sur les documents officiels publiés par le gouvernement russe et le gouvernement ottoman. (Paris: J. Dumaine, 1879-85), Vol.4, pp.83, 87.

52. The ' 93 Harbi' Collection of the Turkish Military Archive in Ankara, ATASE, contains numerous of such correspondences.

53. See Toumarkine, 'Entre empire ottoman et état-nation Turc', Vol.1, pp.145-8.

54. PRO, FO 195/1381 (British Consul at Trabzon writes: 'Tsorooksooli Ali Pacha, who as the head of Laz [=Georgian] volunteers, distinguished himself during the last war with Russia, and is one of the principal agents for the Laz migration from the territory ceded to that power...'). 
55. See AE, CE, Trebizonde, 1876-1880, No.184. As far as the report points out, Osman Pasha was then the kaymakam of Batum and he asked from the government to authorize himself as the Commissioner for the affairs of the Georgians who were preparing for migration to Turkey.

56. Since I have found no hint in the available documentation either in Ottoman archives in Istanbul or in the ATASE archive in Ankara about whether the Pasha had in the last moment (after the region was evacuated by the Ottoman armies in September 1878) been sent back to Batum-Çürüksu region to administer the actual process of migration, I assume that he was still in Istanbul during the first wave of the migrations.

57. PRO, FO 195/1381 (The British Consul at Trabzon writes: 'Ali Pacha assured his majesty that in case of war he would be ready to take part in the struggle with a Corps of four or five thousands volunteers. I have no doubt that the Lazes who are very warlike, Ordou [= Ordu] where Ali Pacha, and his brother Osman Pacha have unbounded influence well answer the call of their chiefs, whenever it may take place ...' '). On the same issue, also see BOA, Y.PRK.UM 4/28 and ID, 66263.

58. BOA, Y.EE 58/24. For the increasing emphasis on the notion of loyalty to the Sultan, the nation and religion under Abdülhamid II, see S. Deringil, The Well-Protected Domains, Ideology and the Legitimation of Power in the Ottoman Empire 1876-1909 (London and New York: I.B. Tauris, 1998), pp.17, 32, 98,108. Compare this rhetoric also with Makdisi's interpretation of the emergence of the new concepts such as nation (=millet) as a manifestation of the Ottoman perception of the 'modern' as well as a point of reference, allegiance, and loyalty of the subjects to the modern state in the nineteenth century Ottoman context. See U. Makdisi, 'Ottoman Orientalism', The American Historical Review, Vol.107, No.3 (2002), pp.782, 787.

59. Apart from the works cited in note 1, see also G. Chochiev and B. Koç, 'Migrants from the North Caucasus in Eastern Anatolia: Some Notes on their Settlement and Adaptation', Journal of Asian History, Vol.40 (2006), pp.80-103; G. Chochiev, 'XIX. Yüzyılın İkinci Yarısında Osmanlı Imparatorluğu'nda Kuzey Kafkas Göçmenlerinin Toplumsal Uyarlanmasına Dair Bazı Görüşler', Kebikeç, Vol.23 (2007), pp.407-56; G. Chochiev, 'Osmanlı Devleti’nde Kuzey Kafkas Göçmenlerinin Toplumsal Uyarlanması Bağlamında 'Çerkes Aşırılıkları' Sorunu (19. Yüzyılın İkinci Yarısı - 20. Yüzyılın Başlangıc1)' (Paper presented at 11th International Congress of Economic and Social History of Turkey, Bilkent; 17-21 June 2008); B. Şimşek, 'Kafkasya'dan Uzunyayla'ya: Çerkes Muhacirlerin Uzunyayla'daki İskan Süreci Üzerine Bazı Notlar' (Paper presented at 11th International Congress of Economic and Social History of Turkey, Bilkent; 17-21 June 2008); S. Yel and A. Gündüz, 'XIX. Yüzyılda Çarlık Rusyası’ nın Çerkesleri Sürgün Etmesi ve Uzunyayla’ya Yerleştirilmeleri (18601865)', Turkish Studies, Vol.3/4 (2008), pp.949-83.

60. Here I am referring to the semi-autonomous character of the Ottoman administration up to the midnineteenth century in the region under the system of yurtluk-ocaklık through which a large amount of local revenue was allocated to the local notable families (such as the Tavdgiritze family of Ali Pasha) in return for their allegiance and administrative duties in the name of the Ottoman Sultan. In addition, there was a sizeable and very influential Georgian community of high ranking bureaucrats and Pashas together with some Georgian women members of the royal household. It seems that Ali Pasha's power and rise in the Ottoman establishment owes a great deal to this imperial networking that kept alive the direct link between the Batum-Çürüksu region and Istanbul. My work on these aspects continues with the hope that I will deal with them in a separate study.

61. Reid, Crisis of the Ottoman Empire, pp.21-3, 198-204.

62. Ibid., pp.102-4, 190-93.

63. See Deringil, The Well-Protected Domains.

64. See Meeker, A Nation of Empire. Cf. E.A. Aytekin, 'Land, Rural Classes, and Law: Agrarian Conflict and State Regulation in the Ottoman Empire, 1830s-1860s' (Unpublished Ph.D. dissertation, Binghamton University, 2006), pp.14-35.

65. See relevant parts of the work by Y. Küçük, Doğu Karadeniz Bölgesi Esskiya ve Kabadayıları, TürkülerDestanlar (Trabzon: Serander Yay., 2006). Compare Reid, Crisis of the Ottoman Empire, for the aspects of civilians victimized during such a factional warfare and terrorism. 